\title{
What do film teachers need to know about cognitivism? Revisiting the work of David Bordwell and other cognitivists
}

\author{
Steve Connolly* - University of Bedfordshire, UK
}

\begin{abstract}
In the pages of the inaugural issue of this journal, the work of film educator Alain Bergala was discussed as a means of exploring possible approaches to film education. While Bergala offers many reasons why young people should be taught about film, there is very little discussion in his work of how they learn. In the subject field of education more broadly, there is currently a great deal of attention given to this process, with classroom teachers in all disciplines being encouraged to consider the ways that cognitive science might inform both instructional design and teaching itself. The popularity of the work of psychologists such as John Sweller and Daniel Willingham can be seen as indicative of a wider, positivist trend in educational research. While, historically, film educators may have seen their pedagogical and curricular activities as being located in a more linguistic, and perhaps interpretivist, domain, it is important to note that there is a cognitive tradition within both film studies and film education, mainly arising from the work of David Bordwell. Bordwell's seminal essay, 'A case for cognitivism' (1989), sets out some initial reasons why both students of film and film educators should be interested in the way that the brain comprehends the moving image. Drawing on and augmenting the work of other cognitivists such as Paul Messaris (1994) and Gavriel Salomon (1979), Bordwell's work makes for important rereading in an educational environment in which there is both some agreement and some scepticism about the significance of the cognitive. This article seeks to outline and critique the most relevant of Bordwell's arguments, taking as its starting point some unanswered questions from my own PhD studies, which led me to the work of both Bordwell and Messaris, and subsequently to identifying some ideas that film teachers may wish to reflect upon in terms of their own classroom practice. At the same time, it locates Bordwell's work in the wider field of cognitive perspectives in education.
\end{abstract}

Keywords: film; cognitivism; constructivism; film education; Bordwell

\section{Introduction: Revisiting a 15-year-old dead end}

This article, or at least the path that led to it, began 15 years ago, while I was conducting an initial literature review for my doctoral research. That thesis, which ended up being about learning progression in video production (Connolly, 2013), began by asking a two-part question. First, how do children learn to watch the moving image? And second, how does that watching have an influence on the moving image texts that they make? While the finished thesis eventually addressed the second of these two questions quite fully, the first lay semi-abandoned in favour of a view of media learning 
that emphasized the cultural influences present in the classroom, rather than any real analysis of the cognitive learning processes present in the watching habits of the students whose work was being analysed. There were two reasons for this: first, my own feelings of inadequacy when it came to employing cognitivist perspectives on learning; and second, because at the time, the broad feeling in the academic community to which I belonged was that learning about moving image texts was, like much other learning, in thrall to what has become known as 'the linguistic turn'. Language and language systems were the predominant way of analysing and explaining learning, and, as such, the role of the brain was not given much thought. Witness, for example, recent discussions of the work of French film educator Alain Bergala in the inaugural issue of the Film Education Journal (Chambers, 2018; Burn, 2018; Gibbs, 2018). In The Cinema Hypothesis (2016), Bergala devotes many pages to why young people should be taught film, but relatively few to the question of how they learn. What discussion there is focuses on film as an art or a language, but with little indication of how this art or language form is acquired.

Now, some 15 years later, there is clearly a need to return to these ideas, not only because of some of the trends in global education (as outlined below) but also because David Bordwell, arguably one of the key thinkers in film studies of the last thirty years, has invested a great deal of thought in exploring how cognitivism fits within his field of study. Bordwell's interest in the cognitive has spawned a wider academic movement of cognitive studies within the moving image, with a number of theorists writing about the way that the brain both apprehends and interprets cinema. Therefore, now seems an apposite point to ask what teachers might need to know about cognitive approaches to the subject of film and how (if at all) such approaches might affect their teaching. In what follows, I will provide a brief summary of Bordwell and his work, before exploring how this relates to some wider thinking about cognitivism in education.

\section{Cognitivism in the classroom: A positivist trend}

Classroom teachers of film and media studies, working with secondary and tertiary age students (particularly in the UK and US, but also further afield) are likely to have noticed that the role of the cognitive is increasingly discussed, both in their schools and on the internet. The terms 'cognitive' and 'cognitivism' can be used to describe a wide range of ideas that seek to provide accounts of perception and learning as being primarily related to the brain and its associated functions (such as visual and auditory perception, memory and mental processes).

In the UK, the endorsement of the work of cognitive psychologists such as Daniel Willingham (2017) and John Sweller (2016a, 2016b), by both other educational researchers (Wiliam, 2017) and the educational establishment more widely, has meant that classroom teachers of film have found themselves grappling with how ideas of cognitive load or dual coding might apply to teaching film. Ostensibly, both ideas are concerned with memory retention, but they have been sold to teachers as a means of ensuring more effective learning. These two ideas make for useful examples of the way in which cognitive psychology has developed an influence over pedagogy. Taken from the field of experimental cognitive psychology, both seem to offer explanations for how students learn and, consequently, how they might be taught.

Cognitive load theory (CLT) presents the idea that there is an optimum amount of mental effort associated with effective learning, and that instructional design (how the teacher plans and delivers the lesson) can affect this effort. Developed by Sweller (2010), CLT proposes that there are three types of cognitive load that the teacher needs 
to manage in order to ensure effective learning: intrinsic, extraneous and germane. Intrinsic load refers to the inherent difficulty of what is being learnt: a mathematical problem such as ' $2+2$ ' creates a small intrinsic load but a quadratic equation creates a larger one. Extraneous load is the effort needed to deal with the way in which what is being learnt is actually delivered. Germane load is the mental effort required to develop what cognitive psychologists term 'schemata' - a term that will be explored later in this article. Sweller's original research found that instructional designs that used problem-solving techniques were less successful than others (such as using a worked example) because they increased the level of extraneous load (Sweller and Cooper, 1985). In effect, such approaches took up more mental effort, which in turn meant that the learner had less effort to expend dealing with the intrinsic load of whatever was being learnt. This has become important for classroom teachers because it has led to a wider debate about teaching methods. In Sweller's studies (which tend to focus on maths and science students), discovery learning methods such as problem-solving prove less effective than others. In a subject such as film, then, the question arises of whether or not cognitive load is an issue. While a film class does not resemble a maths class in many ways, the role of mental effort clearly requires consideration if we want to consider what constitutes effective teaching.

The notion of dual coding explores similar concerns. Originally suggested by Canadian psychologist Allan Paivio (1986), dual coding is built on the idea that verbal information and visual information are processed differently by the brain. One of the implications of Paivio's research was that a number of his experiments appeared to show that combining pictures and words in instructional materials improved memory recall. While such an outcome is of interest to teachers preparing students for examinations, it also may have implications for film students more broadly, in exploring how films combine words, images and other modes of communication.

Along with other ideas from cognitive psychology (such as computational thinking (Wing, 2008)), these theories have become part of an increasingly dominant discourse in education. Such a trend is reflective of a wider, more positivist approach to educational research in which there is a movement in some parts of both academia and education systems worldwide to apply lessons learnt from science (and particularly medical science) to teaching and learning. Putting aside for a moment possible philosophical objections to this position and the wider 'what works' agenda - as neatly summarized by Gert Biesta (2010) in his essay 'Why "what works" still won't work' - it would be easy for film teachers to simply reject all of the noise surrounding discussions of the cognitive on the grounds that film is an art form, concerned with emotions, feelings and opinions that can only be theorized in an interpretive, linguistic way. However, for David Bordwell, a film academic with whom many classroom teachers of film may be familiar, the traditional interpretive and linguistic accounts of how film is watched and learnt do not tell the whole story. As a consequence, Bordwell has spent the second half of his career exploring how the brain reacts to the moving image, and how this affects how we watch and think about film.

It is important to note right from the start that for Bordwell, cognitivism is simply one account of how film watching might occur and be learnt. It would clearly be foolish for a theorist whose most well-known work is entitled Film Art: An introduction (Bordwell and Thompson, 1993) to subsequently reject outright the aesthetic and interpretive foundations of film studies. Bordwell (1989: 11) himself, in his seminal essay 'A case for cognitivism', is quick to rule out suggestions that cognitivism is 'one of those Big Theories of Everything ... it seems to me that no single mega-theory can comprehend the diversity of cinematic phenomena'. Interestingly, psychologist 
John Sweller (2016b: 14) is very clear that his development of cognitive load theory should be seen in the same way, remarking that CLT 'is not a theory of everything', and that it will not work as an efficient model of teaching and learning in every educational situation. For Bordwell (1989: 14), faced with the accusation of positivism (or perhaps, more accurately, scientism) by his critics, this is an important point because, as he reminds his readers, no natural science 'purport[s] to arrive at the absolute truth, only successive approximations to real processes'. These observations should allow those of us non-scientists who continue to enjoy the linguistic, intepretivist tradition within film studies to breathe more easily. Bordwell is clear that cognitivism is not a threat to what has gone before, and continues to go on, in film classrooms the world over. Rather, it is the case that, in exploring cognitive accounts of watching film, he is looking for explanations to go alongside explications. This paper therefore aims to answer three questions: (1) Which aspects of Bordwell's work on cognitivism are likely to be most useful and relevant to teachers of film? (2) How have other theorists both built on and influenced Bordwell's work in a way that might be useful and relevant to teachers of film? and (3) How might these ideas actually affect what teachers do in the classroom, if at all?

In answer to the first question, mainly for reasons of space, I pick out three key ideas from Bordwell's writing that I feel are useful to educators, while an answer to the second question involves revisiting the work of two cognitive thinkers who influenced Bordwell (and, in turn, influenced those who have come after him). Answering the third question is a little more challenging, but presents some interesting challenges to the orthodoxies of teaching film in the secondary school classroom in particular.

\section{Cognitivism: All in the mind?}

For Bordwell (1989), as for many other cognitivists (and, indeed, for many academics in any field these days), cognitive theories interested in exploring how people watch and learn to understand film involve an acceptance of what philosophers term 'mindbrain identity theory'. This is a form of materialism that, broadly, states that the mind and the brain are the same thing. In other words, processes such as comprehension, perception and memory are simply brain states that are largely biological in origin. As a consequence, watching a film and understanding it become a matter of how the film and its meaning are constructed by the brains of the audience. This is an important point, because in Bordwell's discussion of the cognitive perspective, it would be easy to lose sight of the fact that he is a constructivist, which is to say that, in his account of learning to watch a film, quite a lot is determined by the viewer. However, Bordwell's (1989: 16) argument is that at least some of that learning involves acquiring a set of codes within which 'the individual constructs identity and meaning', and that such an acquisition requires a set of pre-existing, innate mental structures allowing viewers to learn the symbolic conventions of film. (These structures, which cognitive psychologists often refer to as 'schemata', and, in particular, the way they relate to the moving image, are further explored by Paul Messaris (1994), whose work will be discussed further below.)

In the first instance, it is important to consider the implications of this argument for teachers. In effect, Bordwell (1989) is arguing that if one accepts a constructivist account of learning, one must accept that some concepts exist a priori (independently of experience), and thus that some aspects of learning film are hardwired into the human brain. Bordwell (ibid.) is particularly sceptical about the idea that the meaning of a film can only be constructed once the viewer has learnt a set of symbolic conventions, the 
position that much film theory seems to adopt - genre theory being a case in point. For teachers, then, cognitivism allows Bordwell to give a much more naturalistic account of watching a film. The fundamental, innate processes with which we apprehend the film are already there, but what the film teacher does is relate those processes to the wider world. A concept such as narrative is, for Bordwell (ibid.), a priori; what the teacher does is to name the concept and explain how it relates to others. This is not dissimilar to Vygotsky's (1986) work on the difference between spontaneous and scientific concepts. Both thinkers can be seen in the cognitive constructivist tradition in that they require some a priori knowledge to be in place before learning can be effective. Perhaps the key difference between the two is that for Vygotsky there must be some social and cultural elements to this learning. In Vygotsky's (ibid.) account of concept formation, the child learns to move from concrete concepts to abstract ones through play and imaginative experimentation. Vygotsky's work would suggest that creative imagination - what he calls fantasy - is one of the key ways that young people learn to move from the concrete to the abstract. While, at the end of 'A case for cognitivism', Bordwell (1989) calls for proper ethnographies of how children learn to watch film and how film-makers learn their craft, he does not seem to connect the two. Fortunately, many other thinkers have done this - including myself (Connolly, 2013,2014 ) - and have suggested that constructivism must have a social as well as a cognitive dimension to it in order for learning to take place. Bordwell chooses this kind of cognitivist constructivism because he finds the kinds of accounts offered by most film theorists to be unsatisfactory. Such accounts, which he says 'usually involve some version of the Lacanian story' (Bordwell, 1989: 20), do not seem to provide any explanation of how the child mis-recognizes itself in the mirror - the mirror stage being that point in mental development that Lacan (1953) identifies as being important for how we form our identity, a theory that is used by some film theorists to explain the relationship between the cinema audience and the way they identify with the camera (Metz, 1974). For this to take place, the theorist must show the conditions that enable such a mis-recognition. In cognitive constructivism, Bordwell suggests that there is a clearer account of how we learn to watch film. It is important to note here, however, that Bordwell is not necessarily concerned with teaching film. His cognitivism is not being pressed into service as the basis for instructional design, as it is in the work of an educational theorist such as Sweller. For Bordwell, cognitivism is a means to an end, explaining how knowledge and meaning of the film are constructed, rather than instructed. The full implications of a cognitivist perspective for film education have yet to be properly investigated, and this is something that I will tentatively begin to explore below.

\section{Schemata: A common mental language for film}

Bordwell (1989) suggests that innate mental structures, or 'schemata', play an important role in how we, as viewers, understand what is happening in a film. He draws upon a wide range of discourses from experimental psychology to suggest that we recognize particular events in the world because they correspond to mental schemata that allow the recognition of that event. Giving the example of buying and selling, Bordwell posits that the schema of 'buying and selling' is something we apply to all sorts of exchanges involving payment that we see both around us and on screen. He goes on to suggest that such schemata are the structures that allow us to make sense of stories. For example, consider a scene early in Mike Newell's Donnie Brasco (1997). Here, one character (Lefty) brings a ring to another (Donnie) with a view to selling it to him. 
Initially, neither talk about selling or buying the ring explicitly, but the audience knows from the way that Lefty handles the ring (he has it wrapped up in a cloth) and the way that Donnie looks at it that at least one of the parties intends such an exchange. For Bordwell (1989: 20), it is our 'buying and selling' schema that allows us to understand what is going on here, despite the fact that Lefty does not explicitly say 'I want to sell this ring.'

Drawing on the work of psychologist Jean Mandler (1984), who argues that the commonality in story structures shared by people in widely differing cultures points towards the existence of such schemata, Bordwell (1989: 20, after Hochberg, 1986) proposes that in film production, film-makers are often required to shoot and edit in such a way that the correct 'perceptual inference' is replicated by the viewer. Here, Bordwell seems to be suggesting that this happens unconsciously, perhaps because the schema is a shared one. Nevertheless, he is pointing towards the idea that there are some aspects of cognition that mean viewers will read a film regardless of their experience of film in general. Such mental representations are shared by many cultures, Bordwell (1989: 20) argues, implying that aspects of filmic representation, such as narrative and genre, and concepts such as personhood, are all schemata. This might then require us to consider how some concepts in film studies are learnt much more swiftly than we might previously have assumed.

From the perspective of teachers working with film in the classroom, one of the interesting things here is that Bordwell is exploring a problem that has recently occupied those cognitive psychologists interested in instructional design, namely how teachers build and develop the schemata that are associated with knowledge of a subject discipline. A detailed introductory account of the role of schemata theory in constructivist accounts of education can be found in Derry (1996). In brief, however, the concerns of educational cognitivists such as Derry and Sweller can be summarized in three key ways. First, schemata are memory structures and can work in both long-term and short-term ways. Previously learnt schemata can be stored as long-term memory and 'activated' (Derry, 1996: 168) when short-term memory (the part of the brain where learning really takes place) needs to draw on them to support new learning. Second, there are different types of schema, which have different roles in learning. Derry (ibid.: 166) identifies three possible types that are useful to teachers: memory objects, mental models and cognitive fields. As discussed above, Bordwell focuses mainly on the second type (the mental model) as being the key schema for understanding film. For film teachers, however, the other two may be important as well.

The memory object is the simplest type of schema. Sweller and Cooper (1985: 59), for example, suggest that it is these mental structures that allow us to 'classify and categorize certain types of experiential input, and that the presence or absence of these schemas may substantially explain the difference between levels of expertise'. For example, some of the skill in being a film editor will be reliant upon the presence of certain memory objects in the editor's brain that allow him or her to deal quickly with certain situations when at the editing station. For film teachers, this might emphasize the need for what K. Anders Ericsson et al. (1993) have termed 'deliberate practice' when working with students who are making their own films. The cognitive field, on the other hand, is a schema that allows certain kinds of memory to be activated, to use Derry's (1996) term. Put simply, the cognitive field is a mental structure that makes a connection between a particular type of activity and a particular memory. So, for example, if I solve the same type of mathematical problem a number of times, I come to associate the problem-solving process with the memory of how to do it. Again, for teachers of film, this might emphasize that watching and rewatching films, alongside 
specific types of activity that anchor the film to particular types of knowledge (class discussion and textual analysis, for example), might be the way that students can retain knowledge of a film that they can reproduce later on in their own academic and creative work. In some ways, this might seem quite obvious, but understanding these schemata is likely to make teachers of film reflect on how the knowledge and skills that they are imparting 'go in and stay in' to the young people they are teaching. Below, I discuss some examples from my research, and they may give some indication as to how both watching and making schemata are being developed in the young people they describe.

The third concern of educational cognitivists is that the development of strong schemata allows us to problem-solve, dealing more effectively with ambiguity and uncertainty. Targeting students' misconceptions about an area of knowledge will allow the teacher to develop particular schemata that allow them to deal with a range of unfamiliar stimuli. This is probably what many film teachers are doing (perhaps consciously, perhaps not) when they equip students with the kind of textual analysis framework that Bordwell and Thompson (1993) themselves propose for studying film. Here, the teaching of, and to, a textual analysis framework is, from a cognitivist perspective, likely to involve the development of cognitive field (the textual analysis framework of camera, mise en scène, editing, sound and so on) built on the mental models that the student uses to recognize what is going on in the film, as described by Bordwell (1989).

To conclude, then, while Bordwell is thinking about schemata in terms of learning to watch film, rather than teaching it, wider schemata theory may be useful for teachers, both in terms of rationalizing what they already do in the classroom, and also for thinking about how they might prepare students to be both knowledgeable and critically aware of what they watch.

\section{Cognitivism: Key to understanding how we watch and make film}

Bordwell (1989) concludes 'A case for cognitivism' by suggesting that one of the most appealing facets of the cognitive perspective is its connection to empirical studies. It is important to reiterate the point made earlier, namely that Bordwell is suggesting that empirical data of all sorts are vital for film studies; but, specifically, what he is arguing at the end of the essay is that an examination of the cognitive aspects of both filmmaking and film watching could provide students of film with an understanding of the knowledge required to shoot and edit film, as well as an understanding of what it is that makes film interpretable. Bordwell is careful to leave the door open for interpretivists both here and in the follow-up article (Bordwell, 1990) he writes in response to some initial criticisms of his arguments. He knows, however, that interpretivist theories of film must be built on something, and he is proposing that a view of film learning that can be empirically tested - such as the cognitivist view - could be one such foundation.

In his conclusion, he also makes a point of stressing that cognitivism may not have all the answers, but it does offer an account of how learning to watch film takes place. Having already acknowledged that people such as Metz (1974) have tried to provide semiotic and symbolic explanations for these things, he concedes that any theory of film is likely to only be 'a little bit right and somewhat useful here and there' (Bordwell, 1989: 37) until it is tested out, and cognitivism at least offers plenty of opportunity for such testing. 
The data for my PhD - which ended up being more of a cultural and critical account of how children learn to watch and make films - may prove to be of some use here. Two examples provide some clues as to the way that cognitive aspects of making and watching film could provide a basis for more interpretive thinking about how learning takes place. The study itself (Connolly, 2013) followed a small group of students across three years and looked at the kind of media production work they did, with a view to finding out how learning progression took place. In addition to the production work itself, all the students were interviewed a number of times about their work, and in some instances they were observed in the production process. The two examples below are selected because they seem to make direct reference to cognitive concerns, namely memory and perception; but because the intention of the study was directed towards the cultural and the critical, they should not be seen as evidence of any kind of cognitive experiment. Rather, they should perhaps be read as signposts in the data, pointing us back towards the potential role of the cognitive in the overall watching and making process.

The first example is taken from an observation of a production class in which a group of 16 year olds is producing the opening to a horror film. The group had done some production work in the previous year - making a documentary short - but this was one of a number of projects that was designed to allow them to practise their film-making and editing skills prior to making a larger project that would be externally assessed as part of their course. During the editing process, one female student is heard to exclaim: 'It's all coming back to me now! I've missed this programme [referring to Adobe Premiere] so much!' (Connolly, 2013: 141-2).

In the study itself, it was posited that this kind of exclamation was indicative of the importance of unfamiliarity in the learning process - that unfamiliarity was something that students had to navigate their way out of by practical experimentation and play - but it also suggests something quite important about memory as well. The re-familiarization that was going on with the editing software was clearly about remembering not only how the software worked, but also what it could do. As a researcher, I felt that this was linked to the way that there was a connection between familiarity with the software and metalanguage, in that consistent use of the software clearly reinforced students' use of the technical vocabulary around a process such as editing. At the time, I identified this reinforcement as being social and cultural - quite a lot of it depended on working in a group and talking about the task in hand using that vocabulary. I still believe this - for me, learning how to watch and make film is largely a socially constructed process - but I also accept that, at some level, there is a cognitive process occurring here as well, alongside the social experience. Some of this remembering, this 'coming back', is about the association of physical actions with what is on the editing screen, and a vocabulary that describes that picture. One job of classroom teachers of film might be to think about ways in which classroom teaching can join up these particular dots: what kinds of teaching can make the memory recall involved in a task such as video editing more efficient and more intuitive for students? Additionally, what kinds of teaching might make the mental connection between those task processes and a critical and conceptual understanding more explicit? Answers to these questions might involve deliberate practice, and perhaps repetition of particular kinds of task, such as low-stakes editing exercises and short-clip analyses, put alongside more developmental, interpretive activity that allows for discussion and exchange of what Luis Moll et al. (1992) have termed 'funds of knowledge'. 
The second example came from a conversation with a student working on a similar project who was talking with me about a shot he wanted to include in his film opening:

Student: We watched Vertigo [1958] and got this idea for a forward tracking zoom out shot thing ...

Teacher: Forward tracking zoom out?

Student: Reverse tracking zoom out ...

Teacher: Huh?

Student: It's the Jaws [1975] shot, kind of thing ... where he looks down but the scenery appears to move forward.

Teacher: Yes ... that's sometimes called a contra-zoom.

Student: Yes, all that really is, is pushing the camera forward and zooming out. (Connolly, 2013: 132)

Culturally, I see this exchange as being about what I term 'thetic criticality' (ibid.: 133). The student is attempting to be critical, and to use a film-making technique that they know will have a particular effect on their audience, but they do not have the correct vocabulary to describe it. It is only at the end of the conversation that the teacher introduces this new term that they can add to their knowledge - an antithetical piece of knowledge that forces them to change what they know about what they are doing and how they do it. However, beyond this cultural process, there is something cognitive at the heart of the exchange as well, something that is to do with how the student perceives the original shot. They recognize that this is something unusual, something done to create a particular effect, and indeed they recognize how it works, but do not have a vocabulary to describe this. Such an instance seems to support the idea put forward by the cognitivists that, to some extent, our brains are programmed to make sense of certain kinds of filmic events. This idea, then, has some appeal as the basis for the kind of social and cultural analyses that I think are essential for understanding film learning, and its origins are worthy of further attention.

\section{The cognitive tradition in visual media studies: Paul Messaris}

When Bordwell wrote 'A case for cognitivism' in 1989, he was part of a wider trend within the study of visual and media arts that saw academics thinking about the way that the brain learnt to apprehend the visual. Paul Messaris's book Visual Literacy, published in 1994, dealt with both the still image and the moving image, and provided some compelling arguments to support the idea that, to some extent, human beings were hardwired to read moving image texts and understand them. For Messaris (1994), the point of studying film was not for the teacher to highlight things that the viewer probably knew already, but rather that it allowed the audience to appreciate the incipient artistry evident in film-making and any ideological or manipulative uses that were at work in the film. His rejection of the idea that visual literacy was anything other than simply building on innate mental structures that we are all equipped with is probably best described by his attitude towards viewers' problems with the comprehension of editing or non-standard camera movements. Messaris (ibid.) asserts that this kind of difficulty is largely caused by a general human inability to correctly 
perceive real-world situations from other people's perspectives. Point-of-view shots, eyeline matches and flashbacks do not really have any parallel outside an individual's own personal perceptual experience, and, as a consequence, they are harder to understand when we see them in a film. He seems to be suggesting that once we are able to relate these unfamiliar viewing experiences to our own experience and apply our film-specific schemata or mental model to them, we are able to comprehend them better. He uses the work of Israeli psychologist Gavriel Salomon for support here. Salomon (1979) had spent much of the late 1970s trying to work out how children learn to watch television, and had conducted some experiments that tried to provide empirical evidence for the idea that the ability to derive particular meanings from an image was connected to the innate mental abilities of the viewer. There is much that is unsatisfactory in Salomon's work in this period - for a fuller account of its limitations, it is worth going back to David Buckingham's (1993) critique - but it did provide Messaris (and, by extension, David Bordwell) with a starting point upon which to build the idea that cognitive science could provide some explanation for how this kind of learning takes place.

These early explorations of the relationship between cognition and moving images are, in some senses, quite rudimentary when considered in the light of some of the significant changes that have occurred in the way audiences consume moving image texts. At the time, neither Messaris nor Salomon had any idea of how the proliferation of digital technologies would change the production and consumption of film. Interestingly, Salomon's later work does consider how cognitive constructivism looks in the digital classroom (Rosen and Salomon, 2007), yet one has the sense, when reading their work some quarter of a century later, that they are asking important and difficult questions about the comprehension of film texts that sit alongside those posed by Bordwell (1989). These are the fledgling expeditions of theorists who would go on to take these cognitivist perspectives to an even deeper level while, at the same time, encouraging others to strike out in new directions.

\section{Bordwell's most recent cognitive work}

Bordwell continues to explore the cognitive aspects of film viewing, both by highlighting the work of academics working in new fields such as eye-scanning and controlled cognition, and at the same time by exploring films he has already analysed by looking at them with a fresh cognitive perspective. Bordwell's own website and blog (www.davidbordwell.net) explore the implications of cognitive science for our understanding of film in such a way as to almost attempt to reinvent film theory itself. His 1996 work, authored with Noel Carroll, entitled Post-Theory: Reconstructing film studies (Bordwell and Carroll, 1996) is a significant point in this process, relying as it does on Bordwell's belief in the importance of mental models but also on Carroll's (1996: 91) belief in the principle that 'movies have engaged the widespread, intense response of untutored audiences throughout the century', and that this engagement is essentially cognitive.

Bordwell's tendency to use his influence to draw attention to these new fields is exemplified by his work with Tim Smith, a cognitive psychologist whose work on eyescanning gives some new perspectives on how we experience film. For Smith, empirical evidence regarding how many viewers fail to spot continuity errors (Smith, 2005; Rayner et al., 2009) gives good indications of how our eyes, and subsequently our attention, are drawn towards particular details - such as faces - which means we miss things such as continuity errors. Some teachers of film in schools may, at this point, ask 'So what?' 
but Smith's work speaks to some wider issues about both the way that film-makers take audiences' inattention for granted on occasion, as well as the distinct possibility that some meanings are lost to audiences because of inattention. This last point is taken up by Bordwell (2010a) himself, who suggests that one of the main 'tasks' we take on when watching a film is to seek out things that maintain our attention. As we follow particular attention-grabbing items on screen, this would suggest that quite a lot of stuff in our field of vision when we watch a film is actually redundant (in effect, we are not following it), which raises the question 'Why is it there?' This is quite an important question for teachers training their students to watch films in terms of textual analysis, primarily because it would appear that the work of both Bordwell (ibid.) and Tim Smith (2005) suggests that the brain is militating against just this sort of analysis. Interestingly, much of Bordwell's recent film analysis work (done alongside his cognitive studies) has focused on drawing attention to the details that audiences might miss. His work on Christopher Nolan's Inception (2010) is a case in point (Bordwell, 2010b), and points towards the idea that one job of the film teacher is to look for the things that audiences miss, encouraging their students to watch, rewatch and produce more complex and, ironically perhaps, interpretive accounts of those film texts. In considering this task, it is useful to reflect on the work of visual theorist Elliot Eisner (2002), who suggests that the arts generally have a number of 'cognitive functions' - in effect, they do specific things to develop understanding, such as noticing more of the world around us, helping us to hold on to specific ideas by representing them in a range of media and allowing us to explore the uncertain. It is perhaps by understanding these functions and tapping in to what they allow people to learn that teachers of film might best be served by cognitive perspectives.

\section{Conclusion: What do film teachers need to know about cognitivism?}

This paper has aimed to do two things. First, it has provided readers with some reasons to go back to the work of David Bordwell and consider, or perhaps reconsider, the cognitive perspective on studying both film and the ways that film might be taught and learnt. Second, it has sought to place this reconsideration in the context of a broader emphasis on the cognitive in education that is taking place in schools and colleges in the UK and other countries. As Bordwell (1989: 33) himself notes at the end of 'A case for cognitivism', 'all this could turn out to be wrong-headed and useless'; however, given that he is writing in 1989, cognitive psychology suggests that he may have been right to entertain the possibility that film viewing has more than a little to do with the brain. For the film teacher, though, this train of thought has been sped up somewhat by the recent tendency to consider the role of the cognitive in relation to both learning and pedagogy. While this paper can only provide the briefest of introductions to these issues, it is hoped that it may point the reader in a suitable direction in terms of further insight.

Interestingly, the criticisms that can be levelled at Bordwell for his position are similar to those that can be levelled at those who propound the cognitive approach to education more generally. Bordwell's biggest critic is the Lacanian film philosopher Slavoj Žižek (2001), who rejects cognitive accounts of film watching on the grounds that they ignore the role of culture in the comprehension of film. For Žižek, there can be no common mental language of cinema because cinema is not and cannot be, as Bordwell (2001) suggests, 'transcultural'. Criticisms of the cognitive turn in education, as represented by people such as John Sweller, involve similar arguments, not only 
from philosophers such as Gert Biesta (2005: 55), who has suggested that 'cognition, knowledge, is only one way to relate to the natural and social world, and not necessarily the most fruitful, important or liberating one', but also from other psychologists working in the field of education (Moreno, 2010; Labaree, 1998), who have argued that there is a tendency for cognitivists to ignore other areas of educational research that explore the interpretive, social and cultural dimensions of schooling.

For the classroom teacher of film, then, Bordwell asks some reasonable questions, and his dissatisfaction with the overall theoretical and cultural project of film studies may strike a chord with colleagues trying to explain Lacanian interpretations of film to groups of teenagers. However, like the loud voices in the educational debate pressing for more reliance on cognitive science, it is important to see Bordwell and those he has influenced as fighting a particular corner of a large room occupied by many thinkers. While his ideas about how we rely on schemata to learn to watch a film, and the role of attention and inattention, clearly provoke some interesting discussions that teachers may both want to think about and bring to the attention of their students, it is probably the case that, for many students, the hermeneutic and interpretive aspects of studying film are significant motivations for doing so. Consequently, then, Dylan Wiliam's suggestion that all learning is about effecting changes in long-term memory (Wiliam, 2017) is thrown into doubt, as studying a film becomes something rather more creative and intangible. What film teachers really need to know about cognitivism is that it is a school of thought that may usefully inform both their subject knowledge and their pedagogy, but that it will not be the only set of ideas that does this.

\section{Notes on the contributor}

Dr Steve Connolly is Senior Lecturer in Teacher Education at the University of Bedfordshire and Visiting Fellow at the Centre for Excellence in Media Practice at the University of Bournemouth. His current research involves thinking about learning processes involved in film and media education and the role of media and film texts in school English. He is the author of a number of journal articles and book chapters about media and film education and media literacy.

\section{Filmography}

Donnie Brasco (US 1997, Mike Newell)

Inception (US/GB 2010, Christopher Nolan)

Jaws (US 1975, Steven Spielberg)

Vertigo (US 1958, Alfred Hitchcock)

\section{References}

Bergala, A. (2016) The Cinema Hypothesis: Teaching cinema in the classroom and beyond. (FilmmuseumSynemaPublikationen 28). Trans. Whittle, M. Vienna: Austrian Film Museum.

Biesta, G. (2005) 'Against learning: Reclaiming a language for education in an age of learning'. Nordisk Pedagogik, 25, 54-66.

Biesta, G.J.J. (2010) 'Why "what works" still won't work: From evidence-based education to valuebased education'. Studies in Philosophy and Education, 29 (5), 491-503.

Bordwell, D. (1989) 'A case for cognitivism'. Iris, 9, 11-40.

Bordwell, D. (1990) 'A case for cognitivism: Further reflections'. Iris, 11, 107-12.

Bordwell, D. (2001) 'Transcultural spaces: Toward a poetics of Chinese film'. Post Script, $20(2-3), 9-25$. 
Bordwell, D. (2010a) 'Now you see it, now you can't'. 'Observations on film art' blog. 21 June. Online. www.davidbordwell.net/blog/2010/06/21/now-you-see-it-now-you-cant/ (accessed 1 March 2018).

Bordwell, D. (2010b) 'Inception; or, dream a little dream within a dream with me'. 'Observations on film art' blog. 6 August. Online. www.davidbordwell.net/blog/2010/08/06/inception-or-dream-alittle-dream-within-a-dream-with-me/ (accessed 2 July 2018).

Bordwell, D. and Carroll, N. (eds) (1996) Post-Theory: Reconstructing film studies. Madison: University of Wisconsin Press.

Bordwell, D. and Thompson, K. (1993) Film Art: An introduction. 4th ed. New York: McGraw-Hill.

Buckingham, D. (1993) Children Talking Television: The making of television literacy. London: Falmer Press.

Burn, A. (2018) 'Reflections on The Cinema Hypothesis: A response to Alain Bergala'. Film Education Journal, 1 (1), 51-63.

Carroll, N. (1996) Theorizing the Moving Image. Cambridge: Cambridge University Press.

Chambers, J. (2018) 'Towards an open cinema: Revisiting Alain Bergala's The Cinema Hypothesis within a global field of film education'. Film Education Journal, 1 (1), 35-50.

Connolly, S. (2013) 'Learning Progression in Secondary Students' Digital Video Production'. Unpublished PhD thesis, Institute of Education, University of London.

Connolly, S. (2014) '21st century artisans: Creativity, craft and techne in digital video production'. Media Education Research Journal, 5 (1), 32-45.

Derry, S.J. (1996) 'Cognitive schema theory in the constructivist debate'. Educational Psychologist, 31 (3-4), 163-74.

Eisner, E.W. (2002) The Arts and the Creation of Mind. New Haven: Yale University Press.

Ericsson, K.A., Krampe, R.T. and Tesch-Romer, C. (1993) 'The role of deliberate practice in the acquisition of expert performance'. Psychological Review, 100 (3), 363-406.

Gibbs, A. (2018) 'Film education otherwise: A response to Bergala's dialectics of cinema and schooling'. Film Education Journal, 1 (1), 90-100.

Hochberg, J. (1986) 'Representation of motion and space in video and cinematic displays'. In Boff, K.R., Kaufman, L. and Thomas, J.P. (eds) Handbook of Human Perception and Performance Vol. 1. New York: John Wiley, 22-1-22-64.

Labaree, D.F. (1998) 'Educational researchers: Living with a lesser form of knowledge'. Educational Researcher, 27 (8), 4-12.

Lacan, J. (1953) 'Some reflections on the ego'. International Journal of Psychoanalysis, 34, 11-17.

Mandler, J.M. (1984) Stories, Scripts, and Scenes: Aspects of schema theory. Hillsdale, NJ: Lawrence Erlbaum Associates.

Messaris, P. (1994) Visual Literacy: Image, mind, and reality. Boulder, CO: Westview Press.

Metz, C. (1974) Film Language: A semiotics of the cinema. Trans. Taylor, M. New York: Oxford University Press.

Moll, L.C., Amanti, C., Neff, D. and Gonzalez, N. (1992) 'Funds of knowledge for teaching: Using a qualitative approach to connect homes and classrooms'. Theory into Practice, 31 (2), 132-41.

Moreno, R. (2010) 'Cognitive load theory: More food for thought'. Instructional Science, 38 (2), 135-41.

Paivio, A. (1986) Mental Representations: A dual coding approach. New York: Oxford University Press.

Rayner, K., Smith, T.J., Malcolm, G.L. and Henderson, J.M. (2009) 'Eye movements and visual encoding during scene perception'. Psychological Science, 20 (1), 6-10.

Rosen, Y. and Salomon, G. (2007) 'The differential learning achievements of constructivist technology-intensive learning environments as compared with traditional ones: A metaanalysis'. Journal of Educational Computing Research, 36 (1), 1-14.

Salomon, G. (1979) 'Media and symbol systems as related to cognition and learning'. Journal of Educational Psychology, 71 (2), 131-48.

Smith, T.J. (2005) 'An Attentional Theory of Continuity Editing'. Unpublished PhD thesis, University of Edinburgh.

Sweller, J. (2010) 'Element interactivity and intrinsic, extraneous and germane cognitive load'. Educational Psychology Review, 22 (2), 123-38.

Sweller, J. (2016a) 'Working memory, long-term memory, and instructional design'. Journal of Applied Research in Memory and Cognition, 5 (4), 360-7.

Sweller, J. (2016b) 'Story of a research program'. Education Review, 23, 1-19.

Sweller, J. and Cooper, G.A. (1985) 'The use of worked examples as a substitute for problem solving in learning algebra'. Cognition and Instruction, 2 (1), 59-89. 
Vygotsky, L. (1986) Thought and Language. Rev. ed. Cambridge, MA: MIT Press.

Wiliam, D. (2017) 'Cognitive load theory'. Presentation to the Wisconsin Mathematics Council Ignite Session, 3 May 2017. Online. www.dylanwiliam.org/Dylan_Wiliams_website/Presentations_ files/2017-05-03\%20WMC\%20lgnite\%20session.pptx (accessed 5 August 2018).

Willingham, D.T. (2017) 'A mental model of the learner: Teaching the basic science of educational psychology to future teachers'. Mind, Brain, and Education, 11 (4), 166-75.

Wing, J.M. (2008) 'Computational thinking and thinking about computing'. Philosophical Transactions of the Royal Society A: Mathematical, Physical and Engineering Sciences, 366 (1881), 3717-25.

Žižek, S. (2001) The Fright of Real Tears: Krzysztof Kieślowski between theory and post-theory. London: BFI Publishing. 